\title{
Weed Management in Kidney Bean with Tank Mixes of S-Metolachlor, Imazethapyr and Linuron
}

\author{
Nader Soltani*, Robert E. Nurse, Peter H. Sikkema \\ University of Guelph Ridgetown Campus, Ridgetown, Canada \\ Email: soltanin@uoguelph.ca
}

Received 26 April 2014; revised 25 May 2014; accepted 7 June 2014

Copyright (C) 2014 by authors and Scientific Research Publishing Inc.

This work is licensed under the Creative Commons Attribution International License (CC BY).

http://creativecommons.org/licenses/by/4.0/

(c) ()

\section{Abstract}

Field studies were conducted in various locations in Ontario during 2011 to 2013 to evaluate smetolachlor, imazethapyr and linuron applied preemergence (PRE) alone and in tankmix combination for the control of troublesome weeds in kidney bean. $S$-metolachlor, imazethapyr, linuron, s-metolachlor + imazethapyr, s-metolachlor + linuron and s-metolachlor + imazethapyr + linuron applied PRE at rates evaluated caused $3 \%$ or less injury in kidney bean. S-metolachlor provided $87 \%$ $91 \%$ control of redroot pigweed, $46 \%-55 \%$ control of common lambsquarters, and $96 \%-97 \%$ control of green foxtail. Imazethapyr provided $93 \%$ - 96\% control of redroot pigweed, $96 \%-99 \%$ control of lambsquarters and $86 \%-93 \%$ control of green foxtail. Linuron provided $82 \%-98 \%$ control of lambsquarters, $82 \%$ - 99\% control of redroot pigweed and $55 \%-85 \%$ control of green foxtail. The tank mixes of s-metolachlor plus imazethapyr, s-metolachlor plus linuron, and s-metolachlor plus imazethapyr plus linuron provided $92 \%-100 \%$ control of lambsquarters, redroot pigweed and green foxtail. Generally, kidney bean yields reflected the level of weed control. Based on these results, tank mixes of s-metolachlor plus imazethapyr, s-metolachlor plus linuron, and smetolachlor plus imazethapyr plus linuron all provide an adequate margin of crop safety and excellent control of redroot pigweed, common lambsquarters and green foxtail in kidney bean.

\section{Keywords}

Biomass, Density, Herbicide Sensitivity, Injury, Kidney Bean, Tolerance, Weed Control, Yield

\section{Introduction}

Dry bean is an important crop in many countries around the world. Ontario has been one of the leading provinc-

\footnotetext{
${ }^{*}$ Corresponding author.
} 
es in dry bean production in Canada where the crop has been grown since the 1940's [1]. In 2013, dry bean growers planted 36,000 hectares of dry beans and produced 83,000 MT of dry bean with a farm-gate value of approximately $\$ 90$ million [2]. Dry bean is a warm season crop which is evaluated based on its seed size, shape and colour and is very sensitive to weed interference due to its short physical characteristics [3]-[7]. In Ontario, yield losses of up to 70\% have been documented in dry bean when weeds were not controlled [8]. Additionally, If weeds are not adequately controlled in dry bean at harvest time, they can interfere with harvesting efficiency and cause staining of the beans, reducing seed quality and marketability [9]-[12]. There are a limited number of herbicide options that provide broad spectrum weed control in dry bean in Ontario. More research is needed to identify herbicides/tank mixes that have an adequate margin of crop safety and provide consistent broad spectrum control of troublesome weeds in dry bean.

S-metolachlor is a chloroacetanilide herbicide that can control annual grasses such as Setaria viridis (L.) Beauv. (green foxtail), Setaria glauca (L.) Beauv. (yellow foxtail), Setaria faberii Herrm. (giant foxtail), Digitaria ischaemum (Schreb) Muhl. (smooth crabgrass), Digitaria sanguinalis (L.) Scop. (large crabgrass), Echinochloa crusgalli (L.) Beauv. (barnyardgrass), Panicum dichotomiflorum Michx. (fall panicum) and Panicum capillare L. (witchgrass) [13] [14].

Imazethapyr is an imidiazolinone herbicide that can control annual broadleaf and some annual grass weeds including Chenopodium album L. (common lambsquarters), Abutilon theophrasti Medic. (velvetleaf), Ambrosia artemesiifolia L. (common ragweed), Amaranthus retroflexus L. (redroot pigweed), Sinapis arvensis L. (wild mustard), Solanum ptycanthum Dun. ex DC. pp. (Eastern black nightshade), Polygonum convolvulus (wild buckwheat.) and other Polygonum spp. [15] [16].

Linuron is a substituted urea herbicide that can control many broadleaf weeds including common lambsquarters, redwood pigweed, common ragweed, velvetleaf, common chickweed [Stellaria media (L.) Cyrillo], smartweed (Polygonum spp.), prostrate knotweed (Polygonum arenastrum L.), wild buckwheat (Polygonum convovulus L.), purslane (Portulaca oleracea L.), shepherd's purse [Capsella bursa-pastoris (L.) Medic.], annual sowthistle (Sonchus oleraceus L.), field pennycress (Thlaspi arvense L.) and wormseed mustard (Erysimum cheiranthoides L.), including acetolactate synthase- and triazine-resistant biotypes [15] [16].

S-metolachlor provides only partial control of some small-seeded broadleaved weeds such as common lambsquarters, redroot pigweed, and nightshades. Imazethapyr can cause significant dry bean injury under some environmental conditions and provides marginal control of common ragweed and common lambsquarters. Linuron does not adequately control troublesome grass weed species in Ontario. Tank mixing s-metolachlor, imazethapyr and linuron have the potential to provide one pass preemergence broad spectrum weed control in dry bean production.

To our knowledge, there has been no study that has compared the effect of tank mixing of s-metolachlor, imazethapyr and linuron applied PRE in kidney bean production. The objective of this study was to evaluate if a one pass preemergence weed control program with tank mixes of s-metolachlor, imazethapyr and linuron would provide full season control of troublesome annual grass and broadleaf weeds with an acceptable margin of crop safety in kidney bean under Ontario environmental conditions.

\section{Materials and Methods}

Field studies were conducted in 2011 to 2013 at the Huron Research Station, Exeter, Ontario and in 2012 at the Greenhouse and Processing Crops Research Centre, Agriculture and Agri-Food Canada, Harrow, Ontario. The soils ranged from Fox sandy loam to Brookston clay loam. Seedbed preparation at all sites consisted of fall moldboard plowing followed by two passes with a field cultivator in the spring.

The experiments were established as a completely randomized block with four replications. Treatments included a weedy and weed free control, s-metolachlor $\left(1050 \mathrm{~g}\right.$ a.i. $\left.\mathrm{ha}^{-1}\right)$, imazethapyr $\left(45 \mathrm{~g}\right.$ a.i. $\left.\mathrm{ha}^{-1}\right)$, linuron $\left(1125 \mathrm{~g}\right.$ a.i. $\left.\mathrm{ha}^{-1}\right)$, linuron $\left(2250 \mathrm{~g}\right.$ a.i. ha $\left.{ }^{-1}\right)$, s-metolachlor + imazethapyr $\left(1050+45 \mathrm{~g}\right.$ a.i. ha $\left.{ }^{-1}\right)$, s-metolachlor + linuron $\left(1050+1125 \mathrm{~g}\right.$ a.i. ha $\left.{ }^{-1}\right)$, s-metolachlor + linuron $\left(1050+2250 \mathrm{~g}\right.$ a.i. ha $\left.{ }^{-1}\right)$, s-metolachlor + imazethapyr + linuron $\left(1050+45+1125 \mathrm{~g}\right.$ a.i. $\left.\mathrm{ha}^{-1}\right)$ and s-metolachlor + imazethapyr + linuron $(1050+45+2250 \mathrm{~g}$ a.i. $\mathrm{ha}^{-1}$ ).

Plots were $3 \mathrm{~m}$ wide (4 rows spaced $0.75 \mathrm{~m}$ apart) and $10 \mathrm{~m}$ long at Exeter and $8 \mathrm{~m}$ long at Harrow. Within each plot there were four rows of 'Red Hawk' kidney bean. Beans were planted in late May to early June of each year. 
Herbicide applications were made with a $\mathrm{CO}_{2}$-pressurized backpack sprayer calibrated to deliver $200 \mathrm{~L} \cdot \mathrm{ha}^{-1}$ of spray solution at a pressure of $240 \mathrm{kPa}$ using ultra low drift nozzles (ULD120-02, Hypro, New Brighton, MN). Treatments were applied one day after seeding and were left undisturbed on the surface of soil. Wee-free plots were maintained weed-free during the season with hand hoeing and cultivation as required.

Dry bean injury was visually estimated on a scale of 0 (no injury) to $100 \%$ (complete plant death) at 1 and 4 weeks after crop emergence (WAE). Percent weed control was visually assessed 4 and 8 WAE using a scale of 0 to $100 \%$ where a rating of 0 was defined as no weed control and a rating of 100 was defined as complete control. Weed density and biomass (shoot dry weight) were also evaluated at $8 \mathrm{WAE}$ by counting and cutting plants at the soil surface in two $0.5 \mathrm{~m}^{2}$ quadrats per plot and separating by species. Plants were dried at $60^{\circ} \mathrm{C}$ to constant moisture and then weighed. Dry bean was considered mature when $90 \%$ of the pods in the weed-free control had turned from green to a golden colour. Beans were harvested from middle 2 rows of each plot with a small plot combine, weight and seed moisture content were recorded, and yields were adjusted to $18 \%$ moisture.

Data were analyzed as an RCBD using PROC MIXED in SAS 9.2. Herbicide treatment was considered a fixed effect, while environment (year-location combinations), the interaction between environment and herbicide treatment, and replicate nested within environment were considered random effects. Significance of the fixed effect was tested using F-test and random effects were tested using a Z-test of the variance estimate. Environments were combined for all variables. The UNIVARIATE procedure was used to test data for normality and homogeneity of variance. For all weed control ratings, the untreated control (assigned a value of zero) was excluded from the analysis. However, all values were compared independently to zero to evaluate treatment differences with the untreated control. To satisfy the assumptions of the variance analyses, injury 1 WAE was square root transformed; injury 4 WAE was log transformed; weed control of AMARE, CHEAL and SETVI at 8 DAE were arcsine square root transformed; AMARE, CHEAL, and SETVI dry weight and density were all log transformed; yield was untransformed. Treatment comparisons were made using Fisher's Protected LSD at a level of $\mathrm{P}<0.05$. Data compared on the transformed scale were converted back to the original scale for presentation of results.

\section{Results and Discussion}

There was no significant interaction between environments and treatments, therefore all data were pooled and averaged over environments.

\subsection{Crop Injury and Yield}

S-metolachlor, imazethapyr, linuron, s-metolachlor + imazethapyr, s-metolachlor + linuron and s-metolachlor + imazethapyr + linuron applied PRE at rates evaluated caused minimal (3\% or less) visible injury in kidney bean at 1 and 4 WAE (Table 1). These results are similar to other studies that have shown less than $4 \%$ injury in kidney bean with linuron applied applied PRE at 1125 and $2250 \mathrm{~g}$ a.i. ha ${ }^{-1}$ [17]. Similarly, imazethapyr and s-metolachlor applied alone or in combination with other herbicides have been shown to cause minimal injury in dry bean with soil applied PRE herbicides including imazethapyr and s-metolachlor [3] [6] [18]-[21]. However, in contrast, other studies have shown as much as $12 \%$ injury in cranberry and kidney beans with linuron applied PRE [22] and 20\% injury in dry bean with imazethapyr and s-metolachlor applied PRE alone or in combination with other herbicides [18] [23].

S-metolachlor, imazethapyr, linuron, s-metolachlor + imazethapyr, s-metolachlor + linuron and s-metolachlor + imazethapyr + linuron applied PRE at rates evaluated increased kidney bean yield compared to the weedy control (Table 1). S-metolachlor, imazethapyr, linuron (low rate) and s-metolachlor + imazethapyr decreased kidney bean yield $41,29 \%, 35 \%$ and $24 \%$ respectively compared to the weed free control treatment (Table 1). However, linuron (high rate), s-metolachlor + linuron and s-metolachlor + imazethapyr + linuron applied PRE treatments provided comparable yield to the weed free control treatment (Table 1).

In other studies, linuron applied PRE at 1125 and $2250 \mathrm{~g}$ a.i. ha ${ }^{-1}$ did not have any adverse effect on the yield of cranberry and kidney bean [22]. In another study, linuron applied PRE at various doses did not cause any adverse effect on the yield of cranberry, kidney and white beans but yield of black bean was reduced $16 \%$ compared to the non-treated control at $2500 \mathrm{~g} \cdot \mathrm{ha}^{-1}$ [17]. Other studies have also shown that imazethapyr and s-metolachlor applied alone or in combination with other herbicides cause no reduction in yield of dry bean [3] [6] [18]-[21]. In contrast, some studies have shown as much as $25 \%$ yield reduction in dry bean with imazethapyr and s-metolachlor applied PRE alone or in combination with other herbicides [18] [23]. 
Table 1. Visual estimates of percent injury 1 and 4 WAE as well as yield with different rates of s-metolachlor, imazethapyr and linuron alone and in combination on kidney bean at Exeter, ON (2011-2013) and Harrow, ON (2012). Means followed by the same letter within a column are not significantly different according to Fisher's Protected LSD at $\mathrm{P}<0.05^{\mathrm{a}}$.

\begin{tabular}{|c|c|c|c|c|c|}
\hline \multirow{4}{*}{$\begin{array}{c}\text { Treatment } \\
\text { Weedy Control }\end{array}$} & \multicolumn{5}{|c|}{ Injury } \\
\hline & \multirow{2}{*}{$\begin{array}{c}\text { Rate } \\
\text { g a.i. ha }{ }^{-1}\end{array}$} & $1 \mathrm{WAE}$ & 4WAE & \multicolumn{2}{|c|}{ Yield } \\
\hline & & \multicolumn{2}{|c|}{$\%$} & \multicolumn{2}{|c|}{ MT ha $^{-1}$} \\
\hline & & 0 & 0 & 0.7 & $\mathrm{f}$ \\
\hline Weed Free & & 0 & 0 & 1.7 & a \\
\hline S-metolachlor & 1050 & 0 & 0 & 1.0 & e \\
\hline Imazethapyr & 45 & 0 & 1 & 1.2 & c-e \\
\hline Linuron & 1125 & 0 & 0 & 1.1 & de \\
\hline Linuron & 2250 & 0 & 0 & 1.4 & $a-d$ \\
\hline S-metolachlor + Imazethapyr & $1050+45$ & 0 & 1 & 1.3 & b-e \\
\hline S-metolachlor + Linuron & $1050+1125$ & 0 & 0 & 1.6 & $\mathrm{ab}$ \\
\hline S-metolachlor + Linuron & $1050+2250$ & 2 & 2 & 1.6 & ab \\
\hline S-metolachlor + Imazethapyr + Linuron & $1050+45+1125$ & 0 & 1 & 1.5 & $a-c$ \\
\hline S-metolachlor + Imazethapyr + Linuron & $1050+45+2250$ & 3 & 2 & 1.4 & $a-d$ \\
\hline
\end{tabular}

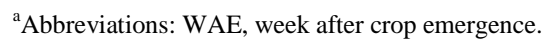

\subsection{Weed Control}

The dominant weed species in this study included redroot pigweed (AMARE), common lambsquarters (CHEAL) and green foxtail (SETVI).

S-metolachlor, imazethapyr, linuron, s-metolachlor + imazethapyr, s-metolachlor + linuron and s-metolachlor + imazethapyr + linuron applied PRE at rates evaluated provided $87 \%-100 \%$ and $82 \%-100 \%$ control of AMARE at 4 and 8 WAE, respectively (Table 2). Generally all herbicide treatments decreased AMARE density and biomass compared to the weedy control (Table 2). There was no difference in density or biomass of AMARE among herbicide treatments or with weed free treatment (Table 2). Results are similar to other studies where imazethapyr at 15 to $75 \mathrm{ha}^{-1}$ combined with dimethenamid $\left(1000 \mathrm{~g} \cdot \mathrm{ha}^{-1}\right)$ controlled AMARE $86 \%$ - 100\% [23]. In other studies with cranberry bean AMARE was controlled $100 \%$ with imazethapyr plus trifluralin and $90-100 \%$ with linuron applied PRE at 1000 and $1500 \mathrm{~g} \cdot \mathrm{ha}^{-1}$ [22].

S-metolachlor provided 46\% - 55\% control of CHEAL (Table 3). Imazethapyr, linuron, s-metolachlor + imazethapyr, s-metolachlor + linuron and s-metolachlor + imazethapyr + linuron applied PRE at rates evaluated provided $96 \%-100 \%$ and $82 \%-100 \%$ control of CHEAL at 4 and 8 WAE, respectively (Table 3 ). All herbicide treatments except s-metolachlor treatment decreased CHEAL density and biomass compared to the weedy control (Table 3). There was no difference in density or biomass of CHEAL among herbicide treatments or with weed free treatment except for s-metolachlor and imazethapyr applied alone which increased CHEAL density and s-metolachlor alone which increased CHEAL biomass compared to other herbicide treatments or weed free treatment (Table 3). Results are similar to other studies in which imazethapyr at 15 to $75 \mathrm{~g} \cdot \mathrm{ha}^{-1}$ plus trifluralin at $600 \mathrm{~g} \cdot \mathrm{ha}^{-1}$ controlled CHEAL 83\% - 100\% [22]. In another study imazethapyr (46 g.ha $\left.{ }^{-1}\right)$ combined with di-

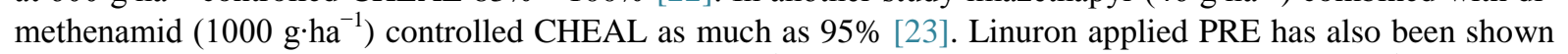
to control CHEAL $11 \%-100 \%$ at 1000 and $1500 \mathrm{~g}^{-h^{-1}}$ and $66 \%-100 \%$ at the 2000 and $2500 \mathrm{~g} \cdot \mathrm{ha}^{-1}$ [22].

Linuron applied PRE at rates evaluated provided 55\% - 85\% control of SETVI (Table 4). S-metolachlor, imazethapyr, s-metolachlor + imazethapyr, s-metolachlor + linuron and s-metolachlor + imazethapyr + linuron applied PRE at rates evaluated provided 93\% - 100\% and 86\% - 100\% control of SETVI at 4 and 8 WAE, respectively (Table 4). All herbicide treatments except linuron treatments decreased SETVI density and biomass com- 
Table 2. Visual estimates of percent AMARE weed control 4 and 8 WAE as well as weed density and dry weight at 8 WAE with different rates of s-metolachlor, imazethapyr and linuron alone and in combination on kidney bean at Exeter, ON (2011-2013) and Harrow, ON (2012). Means followed by the same letter within a column are not significantly different according to Fisher's Protected LSD at $\mathrm{P}<0.05^{\mathrm{a}}$.

\begin{tabular}{|c|c|c|c|c|c|c|c|c|}
\hline \multirow{4}{*}{$\begin{array}{c}\text { Treatment } \\
\text { Weedy Control }\end{array}$} & \multicolumn{6}{|c|}{ Weed Control } & & \\
\hline & \multirow{3}{*}{$\begin{array}{c}\text { Rate } \\
\text { g a.i. ha }{ }^{-1}\end{array}$} & $4 \mathrm{WAE}$ & \multicolumn{2}{|c|}{$8 \mathrm{WAE}$} & \multirow{2}{*}{\multicolumn{2}{|c|}{$\begin{array}{l}\text { Density } \\
\text { plant \# }\end{array}$}} & \multirow{2}{*}{\multicolumn{2}{|c|}{$\begin{array}{c}\text { Dry Weight } \\
\text { grams }\end{array}$}} \\
\hline & & \multicolumn{3}{|c|}{$\%$} & & & & \\
\hline & & 0 & 0 & d & 2.0 & $\mathrm{~b}$ & 5.7 & $\mathrm{~b}$ \\
\hline Weed Free & & 100 & 100 & a & 0.0 & a & 0.0 & a \\
\hline S-metolachlor & 1050 & 87 & 91 & bc & 0.3 & a & 1.5 & $a b$ \\
\hline Imazethapyr & 45 & 93 & 96 & $\mathrm{a}-\mathrm{c}$ & 0.0 & a & 0.0 & a \\
\hline Linuron & 1125 & 92 & 82 & c & 0.3 & a & 0.3 & a \\
\hline Linuron & 2250 & 98 & 90 & bc & 0.0 & a & 0.0 & $\mathrm{a}$ \\
\hline S-metolachlor + Imazethapyr & $1050+45$ & 98 & 99 & $\mathrm{ab}$ & 0.2 & a & 0.7 & a \\
\hline S-metolachlor + Linuron & $1050+1125$ & 99 & 96 & $\mathrm{a}-\mathrm{c}$ & 0.0 & a & 0.0 & a \\
\hline S-metolachlor + Linuron & $1050+2250$ & 100 & 98 & $\mathrm{ab}$ & 0.0 & a & 0.0 & a \\
\hline S-metolachlor + Imazethapyr + Linuron & $1050+45+1125$ & 100 & 99 & $a b$ & 0.0 & a & 0.0 & a \\
\hline S-metolachlor + Imazethapyr + Linuron & $1050+45+2250$ & 100 & 100 & a & 0.0 & a & 0.0 & a \\
\hline
\end{tabular}

${ }^{\mathrm{a}}$ Abbreviations: AMARE, redroot pigweed; WAE, week after crop emergence.

Table 3. Visual estimates of percent CHEAL weed control 4 and 8 WAE as well as weed density and dry weight at 8 WAE with different rates of s-metolachlor, imazethapyr and linuron alone and in combination on kidney bean at Exeter, ON (2011-2013) and Harrow, ON (2012). Means followed by the same letter within a column are not significantly different according to Fisher's Protected LSD at $\mathrm{P}<0.05$. $^{\mathrm{a}}$

\begin{tabular}{|c|c|c|c|c|c|c|c|c|c|}
\hline \multicolumn{10}{|c|}{ Weed Control } \\
\hline \multirow{3}{*}{$\begin{array}{c}\text { Treatment } \\
\text { Weedy Control }\end{array}$} & \multirow{3}{*}{$\begin{array}{c}\text { Rate } \\
\text { g a.i. ha }{ }^{-1}\end{array}$} & \multicolumn{2}{|c|}{$4 \mathrm{WAE}$} & \multicolumn{2}{|c|}{$8 \mathrm{WAE}$} & \multirow{2}{*}{\multicolumn{2}{|c|}{$\begin{array}{l}\text { Density } \\
\text { plant \# }\end{array}$}} & \multirow{2}{*}{\multicolumn{2}{|c|}{$\begin{array}{c}\text { Dry Weight } \\
\text { grams }\end{array}$}} \\
\hline & & \multicolumn{4}{|c|}{$\%$} & & & & \\
\hline & & 0 & $\mathrm{C}$ & 0 & $\mathrm{~d}$ & 7.4 & $\mathrm{~d}$ & 23.8 & $\mathrm{~b}$ \\
\hline Weed Free & & 100 & $\mathrm{a}$ & 100 & $\mathrm{a}$ & 0.0 & $\mathrm{a}$ & 0.0 & $\mathrm{a}$ \\
\hline S-metolachlor & 1050 & 55 & $\mathrm{~b}$ & 46 & $\mathrm{C}$ & 3.5 & $\mathrm{~cd}$ & 23.5 & $\mathrm{~b}$ \\
\hline Imazethapyr & 45 & 96 & $\mathrm{a}$ & 99 & $\mathrm{a}$ & 1.3 & bc & 1.2 & $\mathrm{a}$ \\
\hline Linuron & 1125 & 96 & $\mathrm{a}$ & 82 & $\mathrm{~b}$ & 0.8 & $\mathrm{ab}$ & 1.2 & $\mathrm{a}$ \\
\hline Linuron & 2250 & 99 & $\mathrm{a}$ & 95 & $\mathrm{ab}$ & 0.2 & $\mathrm{ab}$ & 0.4 & $\mathrm{a}$ \\
\hline S-metolachlor + Imazethapyr & $1050+45$ & 98 & $\mathrm{a}$ & 100 & $\mathrm{a}$ & 0.3 & $\mathrm{ab}$ & 0.7 & $\mathrm{a}$ \\
\hline S-metolachlor + Linuron & $1050+1125$ & 98 & a & 92 & $\mathrm{ab}$ & 0.8 & $\mathrm{ab}$ & 1.5 & $\mathrm{a}$ \\
\hline S-metolachlor + Linuron & $1050+2250$ & 99 & a & 97 & $\mathrm{ab}$ & 0.0 & $\mathrm{a}$ & 0.0 & $\mathrm{a}$ \\
\hline S-metolachlor + Imazethapyr + Linuron & $1050+45+1125$ & 100 & $\mathrm{a}$ & 99 & $\mathrm{a}$ & 0.0 & $\mathrm{a}$ & 0.0 & $\mathrm{a}$ \\
\hline S-metolachlor + Imazethapyr + Linuron & $1050+45+2250$ & 100 & $\mathrm{a}$ & 100 & $\mathrm{a}$ & 0.0 & $\mathrm{a}$ & 0.0 & $\mathrm{a}$ \\
\hline
\end{tabular}

a Abbreviations: CHEAL, common lambsquarters; WAE, week after crop emergence. 
Table 4. Visual estimates of percent SETVI weed control 4 and 8 WAE as well as weed density and dry weight at 8 WAE with different rates of s-metolachlor, imazethapyr and linuron alone and in combination on kidney bean at Exeter, ON (2011-2013) and Harrow, ON (2012). Means followed by the same letter within a column are not significantly different according to Fisher's Protected LSD at $\mathrm{P}<0.05$. $^{\mathrm{a}}$

\begin{tabular}{|c|c|c|c|c|c|c|c|c|c|}
\hline \multirow{4}{*}{$\begin{array}{c}\text { Treatment } \\
\text { Weedy Control }\end{array}$} & \multicolumn{7}{|c|}{ Weed Control } & & \\
\hline & \multirow{3}{*}{$\begin{array}{c}\text { Rate } \\
\text { g a.i. ha }{ }^{-1}\end{array}$} & \multicolumn{2}{|c|}{4 WAE } & \multicolumn{2}{|c|}{$8 \mathrm{WAE}$} & \multirow{2}{*}{\multicolumn{2}{|c|}{$\begin{array}{l}\text { Density } \\
\text { plant \# }\end{array}$}} & \multirow{2}{*}{\multicolumn{2}{|c|}{$\begin{array}{c}\text { Dry Weight } \\
\text { grams }\end{array}$}} \\
\hline & & \multicolumn{4}{|c|}{$\%$} & & & & \\
\hline & & 0 & e & 0 & e & 29.3 & c & 87.2 & $\mathrm{~b}$ \\
\hline Weed Free & & 100 & $\mathrm{a}$ & 100 & a & 0.0 & $\mathrm{a}$ & 0.0 & a \\
\hline S-metolachlor & 1050 & 97 & $\mathrm{ab}$ & 96 & $a b$ & 0.8 & a & 0.4 & a \\
\hline Imazethapyr & 45 & 93 & bc & 86 & bc & 6.8 & bc & 2.9 & a \\
\hline Linuron & 1125 & 73 & $\mathrm{~d}$ & 55 & $\mathrm{~d}$ & 11.1 & bc & 26.6 & $\mathrm{~b}$ \\
\hline Linuron & 2250 & 85 & $\mathrm{~cd}$ & 73 & c & 2.0 & $a b$ & 3.2 & a \\
\hline S-metolachlor + Imazethapyr & $1050+45$ & 100 & $\mathrm{a}$ & 99 & $\mathrm{a}$ & 0.5 & a & 0.2 & a \\
\hline S-metolachlor + Linuron & $1050+1125$ & 99 & $\mathrm{a}$ & 99 & a & 0.5 & a & 0.7 & a \\
\hline S-metolachlor + Linuron & $1050+2250$ & 99 & a & 98 & a & 0.3 & $\mathrm{a}$ & 0.8 & a \\
\hline S-metolachlor + Imazethapyr + Linuron & $1050+45+1125$ & 100 & a & 100 & a & 0.1 & a & 0.0 & a \\
\hline S-metolachlor + Imazethapyr + Linuron & $1050+45+2250$ & 100 & $\mathrm{a}$ & 100 & a & 0.0 & a & 0.0 & $\mathrm{a}$ \\
\hline
\end{tabular}

abbreviations: SETVI, green foxtail; WAE, week after crop emergence.

pared to the weedy control (Table 4). There was no difference in density or biomass of SETVI among herbicide treatments or with weed free treatment except for linuron which increased SETVI density and biomass compared to other herbicide treatments or weed free treatment (Table 4). Results are similar to other studies in which imazethapyr plus trifluralin and the sequential application of imazethapyr plus trifluralin PPI followed by linuron PRE at various doses controlled SETVI 97\% - 100\% in cranberry bean [22]. In other studies, imazethapyr $\left(15 \mathrm{~g} \cdot \mathrm{ha}^{-1}\right)$ plus trifluralin $\left(600 \mathrm{~g} \cdot \mathrm{ha}^{-1}\right)$ controlled SETVI greater than 98\% and imazethapyr plus dimethenamid (18 $\mathrm{g} \cdot \mathrm{ha}^{-1}+1000 \mathrm{~g} \cdot \mathrm{ha}^{-1}$ ) controlled SETVI 95\% in dry bean [23].

\section{Conclusion}

Based on this research, s-metolachlor, imazethapyr, linuron, s-metolachlor + imazethapyr, s-metolachlor + linuron and s-metolachlor + imazethapyr + linuron applied PRE at rates evaluated had an adequate margin of crop safety for use in kidney bean. S-metolachlor provided excellent full season control of redroot pigweed and green foxtail and poor control of lambsquarters. Imazethapyr provided excellent control of lambsquarters, redroot pigweed and poor control of green foxtail. Linuron at $1125 \mathrm{~g}$ a.i. ha ${ }^{-1}$ provided excellent control of lambsquarters and redroot pigweed and poor control of green foxtail. Increasing the rate of linuron to $2250 \mathrm{~g}^{\mathrm{a} . \mathrm{i}}$. ha ${ }^{-1}$ resulted in excellent control of lambsquarters and redroot pigweed and good control of green foxtail. The tank mixes of s-metolachlor plus imazethapyr, s-metolachlor plus linuron and s-metolachlor plus imazethapyr plus linuron all provided excellent control of lambsquarters, redroot pigweed and green foxtail. Generally, kidney bean yields reflected the level of weed control. Based on these results, tank mixes of s-metolachlor plus imazethapyr, s-metolachlor plus linuron and s-metolachlor plus imazethapyr plus linuron all had an adequate margin of crop safety and provided excellent control of annual broadleaf and grass species in kidney bean production in Ontario.

\section{Acknowledgements}

The authors would like to acknowledge Todd Cowan for his expertise and technical assistance in these studies. Funding for this project was provided by the Ontario Bean Growers and the CanAdvance program of Agricultural Adaptation Council. 


\section{References}

[1] Agriculture and Agri-Food Canada (2013) Canada: Dry Bean Imports and Exports. http://www.agr.gc.ca/eng/industry-markets-and-trade/statistics-and-market-information/by-product-sector/crops/pulses -and-special-crops-canadian-industry/dry-bean/?id=1174576605314

[2] Kulasekera, K. (2013) Estimated Area, Yield, Production and Farm Value of Specified Field Crops, Ontario, 20012012, (Metric Units). http://www.omafra.gov.on.ca/english/stats/crops/estimate_metric.htm.

[3] Arnold, N.R., Murray, W.M., Gregory, J.E. and Smeal, D. (1993) Weed Control in Pinto Beans (Phaseolus vulgaris) with Imazethapyr Combinations. Weed Technology, 7, 361-364.

[4] Bauer, T.A., Renner, K.A., Penner, D. and Kelly J.D. (1995) Pinto Bean (Phaseolus vulgaris) Varietal Tolerance to Imazethapyr. Weed Science, 43, 417-424.

[5] Blackshaw, R.E. and Esau, R. (1991) Control of Annual Broadleaved Weeds in Pinto Beans (Phaseolus vulgaris). Weed Technology, 5, 532-538.

[6] Urwin, C.P., Wilson, R.G. and Mortensen, D.A. (1996) Responses of Dry Edible Bean (Phaseolus vulgaris) Cultivars to Four Herbicides. Weed Technology, 10, 512-518.

[7] Wilson, R.G. and Miller, S.D. (1991). Dry Edible Bean (Phaseolus vulgaris) Responses to Imazethapyr. Weed Technology, 5, 22-26.

[8] Malik, V.S., Swanton, C.J. and Michaels, T.E. (1993) Interaction of White Bean (Phaseolus vulgaris) Cultivars, Row Spacing, and Seeding Density with Annual Weeds. Weed Science, 41, 62-68.

[9] Wilson, R.G. (1993) Wild Proso Millet (Panicum miliaceum) Interference in Dry Bean (Phaseolus vulgaris). Weed Science, 41, 607-610.

[10] Zimdahl, R.L. (1980) Weed-Crop Competition. International Plant Protection Center, Corvallis, 73-74.

[11] Bassett, I.J. and Munro, D.B. (1985) The Biology of Canadian Weeds. 67. Solanum ptycanthum Dun., S. nigrum L., and S. sarrachoides Sendt. Canadian Journal of Plant Science, 65, 401-414. http://dx.doi.org/10.4141/cjps85-055

[12] Ogg, A.G. and Rogers, B.S. (1989) Taxonomy, Distribution, Biology, and Control of Black Nightshade (Solanum nigrum) and Related Species in the United States and Canada. Rev. Weed Science, 4, 25-58.

[13] Moseley, M.C. and Hagood, E.S. (1990) Reducing Herbicide Inputs When Establishing No-Till Soybeans (Glycine max). Weed Technology, 4, 14-19.

[14] Osborne, T.B., Shaw, R.D. and Ratliff, L.R. (1995) Soybean (Glycine max) Cultivar Tolerance to SAN 582H and Metolachlor as Influenced by Soil Moisture. Weed Science, 43, 288-292.

[15] [OMAFRA] Ontario Ministry of Agriculture, Food, and Rural Affairs (2011) Guide to Weed Control. Publication 75, Ontario Ministry of Agriculture, Food, and Rural Affairs, Toronto.

[16] Senseman, S.A. (2007) Herbicide Handbook. 9th Edition, Weed Science Society of America, Champaign, 458 p.

[17] Soltani, N., Shropshire, C. and Sikkema, P.H. (2013) Response of Cranberry and Kidney Beans to Linuron. Agricultural Sciences, 4, 649-653. http://dx.doi.org/10.4236/as.2013.412087

[18] Renner, K.A. and Powell, G.E. (1992) Responses of Navy Bean (Phaseolus vulgaris) and Wheat (Triticum aestivum) Grown in Rotation to Clomazone, Imazethapyr, Bentazon, and Acifluorfen. Weed Science, 40, 127-133.

[19] Sikkema, P., Soltani, N., Shropshire, C. and Cowan, T. (2004) Sensitivity of Kidney Beans (Phaseolus vulgaris) to Soil Applications of S-Metolachlor and Imazethapyr. Canadian Journal of Plant Science, 84, 405-407. http://dx.doi.org/10.4141/P03-069

[20] Soltani, N., Shropshire, C., Cowan, T. and Sikkema, P. (2003) Tolerance of Cranberry Beans (Phaseolus vulgaris) to Soil Applications of S-Metolachlor and Imazethapyr. Canadian Journal of Plant Science, 83, 645-648. http://dx.doi.org/10.4141/P03-006

[21] Soltani, N., Shropshire, C., Cowan, T. and Sikkema, P. (2004) Tolerance of Black Beans (Phaseolus vulgaris) to Soil Applications of S-Metolachlor and Imazethapyr. Weed Technology, 18, 166-173. http://dx.doi.org/10.1614/WT-03-044R

[22] Soltani, N., Nurse, R.E., Shropshire, C. and Sikkema, P.H. (2011) Weed Management in Cranberry Bean with Linuron. Canadian Journal of Plant Science, 91, 881-888.

[23] Blackshaw, R. E. and Saindon, G. (1996) Dry Bean (Phaseolus vulgaris) Tolerance to Imazethapyr. Canadian Journal of Plant Science, 76, 915-919. http://dx.doi.org/10.4141/cjps96-153 